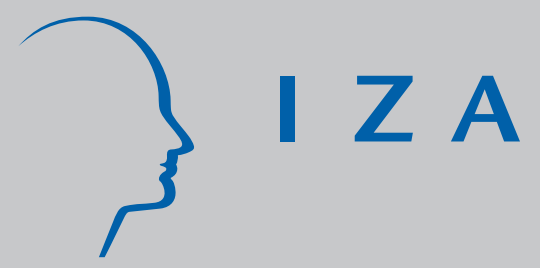

IZA DP No. 214

Family Structure and Female Labour Supply in Mexico City

\author{
Xiaodong Gong \\ Arthur van Soest \\ November 2000
}




\title{
Family Structure and Female Labour Supply in Mexico City
}

\author{
Xiaodong Gong \\ IZA, Bonn
}

Arthur van Soest

Tilburg University

Discussion Paper No. 214

November 2000

\author{
IZA \\ P.O. Box 7240 \\ D-53072 Bonn \\ Germany \\ Tel.: +49-228-3894-0 \\ Fax: +49-228-3894-210 \\ Email: iza@iza.org
}

This Discussion Paper is issued within the framework of IZA's research area The Future of Work. Any opinions expressed here are those of the author(s) and not those of the institute. Research disseminated by IZA may include views on policy, but the institute itself takes no institutional policy positions.

The Institute for the Study of Labor (IZA) in Bonn is a local and virtual international research center and a place of communication between science, politics and business. IZA is an independent, nonprofit limited liability company (Gesellschaft mit beschränkter Haftung) supported by the Deutsche Post AG. The center is associated with the University of Bonn and offers a stimulating research environment through its research networks, research support, and visitors and doctoral programs. IZA engages in (i) original and internationally competitive research in all fields of labor economics, (ii) development of policy concepts, and (iii) dissemination of research results and concepts to the interested public. The current research program deals with (1) mobility and flexibility of labor markets, (2) internationalization of labor markets and European integration, (3) the welfare state and labor markets, (4) labor markets in transition, (5) the future of work, (6) project evaluation and (7) general labor economics.

IZA Discussion Papers often represent preliminary work and are circulated to encourage discussion. Citation of such a paper should account for its provisional character. 
IZA Discussion Paper No. 214

November 2000

\begin{abstract}
Family Structure and Female Labour Supply in Mexico City*

This paper investigates labour supply of married women in Mexico City. A static neoclassical structural mode is used. We assume that each woman chooses her labour supply and corresponding income so that her utility is maximized, conditional upon her husband 's labour supply and earnings. We use a direct translog specification, and include family composition variables as taste shifters. Also taken into account are fixed costs of working, random preferences, and correlation between error terms in wage equations and random preference terms.

The wage equation and the labour supply model are estimated jointly by smooth simulated maximum likelihood. We find income elasticities of labour supply of about -0.17 , and wage elasticities of about 0.87 . The latter is substantially underestimated if the correlation between wage equation errors and random preference terms is not taken into account. We find evidence that the presence of other adult females reduces the negative impact of young children on the mothers' labour supply.
\end{abstract}

JEL Classification: $\quad$ C31, C35, J16, J22, O54

Keywords: Female labour supply, family structure, discrete regression

Xiaodong Gong

IZA

P.O. Box 7240

D-53072 Bonn

Germany

Tel.: +492283894527

Fax: +492283894510

Email: gong@iza.org

\footnotetext{
* Elizabeth Villagomez is gratefully acknowledged for her help and for providing the data. We thank Rob Euwals, Christopher Flinn and an anonymous referee for useful comments and suggestions. Research of the second author has been made possible by a fellowship of the Netherlands Royal Academy of Arts and Sciences (KNAW).
} 


\section{Introduction}

We analyze labour supply and labour force participation of married women in Mexico City. Labour force participation of women in Mexico is low. For example, in 1987, $45 \%$ of females (age 15 to 64 ) in EC countries and $55 \%$ of females in the seven major industrialized countries were employed (CBS, 1993), while according to our 1992 survey, only $38 \%$ of women (age 15 to 64) were employed in Mexico City. For the urban areas of Mexico as a whole, the women's participation rate was 36\% in 1993 (Fleck and Sorrentino, 1994). We aim at explaining this phenomenon using a structural model of female labour supply. Such models have been estimated for many countries, but this is, to our knowledge, the first such study for Mexico. This seems particularly interesting since Mexico shares characteristics of industrialized and developing countries. It has gone through a period of serious economic transition and as of 1992, its per capita income (measured at purchasing power parity) is about that of lower income OECD countries such as Greece and Turkey.

As usual in this type of analysis, we estimate wage and other income elasticities. Moreover, we focus on the role of family structure, which is a potentially important determinant of labour supply. The average family in Mexico City had 4.1 persons in 1992. About $20 \%$ of the families had more than five persons and about $26 \%$ of the households were extended families, i.e. contain members other than head, partner, and their children. In many families, the presence of other females offers a potential substitute for child care services. In developing countries, large size and complicated composition of families are prevalent and influence people's behaviour. This has received little emphasis in the empirical structural labour supply literature. An exception is Newman and Gertler (1994), who examine rural Peru. They find that family structure closely relates to household production and labour supply; the family values the leisure of various members differently, and the own marginal return to farm work is affected by the amount of work performed by other family members.

Wong and Levine (1992) study the effect of household structure on labour force participation of recent mothers in urban Mexico. They formulate reduced-form equations of female labour force participation and fertility. They find that the presence of a "mother substitute" significantly increases the labour force participation of females who have newly given birth to a child. Such findings are not confined to developing countries. Tienda and 
Glass (1985), using a similar model, find that in the US, the presence of other adults increased the probability of labour force participation of mothers who were heads of households. Neither Wong and Levine (1992) nor Tienda and Glass (1985) use a structural labour supply model.

Our data define a household as "the set of individuals living in the same house sharing a common income (provided by one or more of the household members) used to cover food, rent and housing expenditures for all the members. This includes individuals living on their own" (see also Villagomez, 1996). This means that households not only include nuclear families but also extended families of more complicated structure. The number of household members in our sample varies from 2 to 19. In some households, servants and their families are also included. We confine ourselves to the female spouse (including cohabiting partners) of the head of the household, and refer to her as the wife or the mother (if she has children).

Our paper differs from previous work by examining one structural model, in which the impact of wages, other income, and family structure on labour force participation and hours worked is analyzed simultaneously. We follow the framework of Van Soest (1995) and its extensions by Callan and van Soest (1995) and Euwals and van Soest (1999), but take a different wage equation estimation strategy, i.e., the wage equation is estimated jointly with the labour supply model. We analyze female labour supply and take the husband's behaviour as given, following, for example, Hausman (1985). This is simpler than the family labour supply model with joint utility maximization used by, for example, Hausman and Ruud (1984). The simplification can be justified by the empirical finding in the latter type of models that cross elasticities of the husband's labour supply with respect to the wife's wage tend to be small (see van Soest, 1995, for example).

The paper is organized as follows. In section II, we describe the model. Section III describes the data, which stem from the Urban Employment Survey conducted in the second quarter of 1992 by Mexico's National Statistics Institute (INEGI). In section IV the estimation results are presented. In section $\mathrm{V}$ we discuss the results of some simulations and sensitivity and misspecification analysis. Section VI concludes. 


\section{Model and Estimation Method}

We follow the discrete choice approach of van Soest (1995). He assumes that the agent maximizes utility over a finite choice set. This approach has several advantages compared to the traditional (continuous) models. ${ }^{1}$ First, it does not require convexity of budget set or preferences. Second, the approach makes it computationally feasible to incorporate nonstandard budget restrictions (fixed costs, hours constraints, nonlinear taxation, unemployment benefits, etc.), which enlarges the scope for policy analysis. Third, flexible functional forms of the direct utility function can be used, without the need for analytic expressions of the labour supply or the expenditure function. Fourth, the stochastic specification can be allowed to be quite rich, for example allowing for unobserved wage rates of nonworkers, for random preferences, and for correlation between error terms in wage equations and random preferences.

We assume that the woman decides on her leisure, $l$, and after-tax income, $y$, composed of her own labour income, her husband's earnings, and her children's earnings. $^{2}$ Leisure is set equal to $T E-h$, where $h$ is working hours per week and $T E$ is the time endowment, which we set equal to 80 hours per week. ${ }^{3}$ We assume that each woman maximizes utility given by the direct translog specification:

$$
U(v)=v^{\prime} A v+b^{\prime} v
$$

where $v=(\log y, \log l)^{\prime}$. $A$ is a symmetric $2 \times 2$ matrix with entries $A_{i j}$, $(i, j=1,2)$, and $b=\left(b_{1}, b_{2}\right)^{\prime}$. Preference variation across individuals through observed and unobserved characteristics is incorporated through one of the parameters:

$$
b_{2}=\sum_{k=1}^{K} \beta_{2 k} x_{k}+\epsilon^{r},
$$

where $x=\left(x_{1}, \ldots, x_{K}\right)^{\prime}$ is a vector of exogenous characteristics, such as age and family composition. The error term $\epsilon^{r}$ is interpreted as random pref-

\footnotetext{
${ }^{1}$ The traditional models are, for example, described in Hausman (1985) and Moffitt (1986).

${ }^{2}$ Due to lack of information in the data, we are not able to consider the nonlabour income of the family, such as asset income.

${ }^{3}$ Setting $T E=80$ hours per week is ad hoc, but results of Van Soest (1995) and Euwals and van Soest (1999) suggest that results are not sensitive to this.
} 
erences due to the unobserved characteristics. It is assumed to be normally distributed with mean zero, independent of $x$.

$U$ is assumed to be increasing in $y$, implying that each woman will choose a point on the frontier of her budget set. Following the standard approach in this type of labour supply models, the woman's before tax wage rate $w$ is assumed not to depend on hours worked. Thus, once $l$ is chosen, after tax income $y$ is determined by $w: y=y(l, w)$.

In the traditional standard continuous model, the individual solves the problem:

$$
\operatorname{Max} U(y, l) \text { s.t. } y \leq y(l, w) \text { and } l \leq T E .
$$

This can be solved using Lagrange techniques, but the shape of the budget set determines the complexity of the solution. Following Van Soest (1995), we use a discrete budget set, replacing the budget frontier given above by some of its points. The optimization problem then becomes:

$$
\operatorname{Max} U(y, l) \text { s.t. }(y, l) \in C S(w)
$$

where the choice set is given by

$$
C S(w)=\{(y, T E-h) ; y=y(T E-h, w) ; h \in\{0, I L, \ldots,(m-1) I L\}\}
$$

Here $I L$ is a fixed interval length for the working hours. These are rounded to a multiple of $I L$ and censored at $(m-1) I L$. The choice set with $m$ points is denoted by $\left\{\left(y_{0}, l_{0}\right), \ldots,\left(y_{m-1}, l_{m-1}\right)\right\}$.

There are two ways to interpret the discrete budget set, with different implications for the optimal number of points and interval length $I L$. First, the discrete budget set can be seen as an approximation to the traditional continuous budget set. The rounding errors then indicate the quality of the approximation, and the larger the hours interval length $(I L)$ is chosen, the larger these errors will be. Rounding errors no longer play a separate role if $I L$ is chosen equal to one, since in our data, observed weekly hours worked are always an integer number. Thus for $I L=1$, the rounding error in the model would coincide with the rounding error in the data.

The other view is to see the labour supply decision as genuinely discrete. The peaked nature of hours distributions in many countries suggests that people often choose between a very limited number of hours earnings combinations. From this point of view, the continuous model is an approximation to a discrete optimization problem. We do not aim at explaining why firms 
offer certain (wage,hours) packages, and do not incorporate the demand side constraints which may lead to the peaked hours distribution. We focus on labour supply and neglect the (wage,hours) bivariate distribution that might be generated by an equilibrium model with explicit modelling of the demand side. In that sense, the interpretation of our framework as reflecting a genuinely discrete labour supply decision under demand side constraints is far-fetched. On the other hand, a model with few points (and large $I L$ ) suffers less from the fact that irregular numbers of hours are hardly ever observed in practice than a continuous model or a model with large $I L$, and may therefore give a better approximation to the equilibrium model with demand side constraints.

We are agnostic towards choosing between these two interpretations. The arguments given above imply, however, that there is some ambiguity in choosing the number of points $m$ and the length of the hours intervals $I L$. It seems important to estimate the model for various values of these parameters and check the robustness of the results for these choices. In our benchmark empirical specification, we use $I L=10$ and $m=8$. We will perform a sensitivity analysis with smaller values of $I L(I L=4,2,1)$ and larger values of $m$ $(m=19,37,73)$.

To the utilities of all the alternatives in the choice set, random disturbances are added as in the multinomial logit model (Maddala, 1983):

$$
U_{j}=U\left(y_{j}, l_{j}\right)+\epsilon_{j}(j=0, \ldots, m-1)
$$

where the $\epsilon_{j}$ are i.i.d. with a type I extreme value distribution, and are independent of $x$ and of other error terms in the model. ${ }^{4} \epsilon_{j}$ cannot be interpreted as random preferences, which are already represented by $\epsilon^{r}$ in (2). Instead, $\epsilon_{j}$ can be seen as the nonsystematic part of utility of alternative $j$. It could reflect an error made by the individual in evaluating alternative $j$, or could, for example, capture demand side phenomena which make alternative $j$ unattractive, such as search costs or other characteristics of jobs with specific numbers of hours. Obviously, the i.i.d. assumption is quite restrictive and implies that the $\epsilon_{j}$ do not follow the natural ordering in the alternatives. One might therefore argue that in a model like ours, where random prefer-

\footnotetext{
${ }^{4}$ It may seem more general to replace $\epsilon_{i}$ by $s \epsilon_{i}$, and to estimate a scale parameter $s$. The scale of the utility function, however, is not identified. As a consequence, setting $s$ equal to one is a way to normalize the scale of the utility function, without loss of generalization (as in the standard multinomial logit model).
} 
ences are already included, the $\epsilon_{j}$ should no longer be needed. While this may be true from an economic modelling point of view, we will see below that the $\epsilon_{j}$ facilitate estimation substantially. Moreover, adding the $\epsilon_{j}$ implies that all outcomes have nonzero probability, even those who would not be rational for any value of the random preference terms, for example due to nonconvexities in the budget set. In this sense the $\epsilon_{j}$ have the same role as the measurement or optimization error in the continuous model of Hausman (1985).

The individual chooses $j$ if $U_{j}$ is larger than the other $U_{i}$. Conditional on $\epsilon^{r}, x$, and $w$, the probability that $j$ is chosen is

$$
\operatorname{Pr}\left[U_{j} \geq U_{i} \text { for all } i\right]=\frac{\exp \left(U\left(y_{j}, l_{j}\right)\right)}{\sum_{i=0}^{m-1} \exp \left(U\left(y_{i}, l_{i}\right)\right)}
$$

Wage rates of nonworkers and some of the workers are not observed. We need a wage equation to take account of this. The wage equation is also needed to allow for correlation between wage rates and random preferences $\left(\epsilon^{r}\right)$. The wage equation is defined as:

$$
\log w=\pi^{\prime} z+\epsilon^{w}
$$

where $z$ is a vector of individual characteristics (education level, for example), $\pi$ is a vector of parameters, and $\epsilon^{w}$ is an error term, assumed to be normally distributed with mean zero, independent of $z$ and $x$. Initially, we assume that $\epsilon^{w}$ is uncorrelated with the random preference term $\epsilon^{r}$ in (2). We relax this assumption below, and allow that $\epsilon^{r}$ and $\epsilon^{w}$ are correlated. Such a correlation may have various explanations. First, unobserved heterogeneity may play a role. One might then expect that those with high productivity also have larger preference for working, i.e., a lower marginal utility of leisure. This would lead to a negative correlation between $\epsilon^{w}$ and $\epsilon^{r}$. Alternatively, measurement errors in the wage rate (which we do not explicitly allow for) may lead to a negative correlation between $\epsilon^{w}$ and labour supply, i.e., to a positive correlation between $\epsilon^{w}$ and $\epsilon^{r}$.

As in van Soest (1995), the model described so far appears to underpredict the number of nonworkers and overpredicts the number of part-time jobs involving a few hours per week. Unobserved fixed costs of working, such as commuting costs or child care costs, might be responsible for this. Because we use a direct utility function, we could incorporate fixed costs in a natural way: fixed costs could be subtracted from income $y$ if $h>0$. The problem with 
this is that it may lead to negative values of income net of fixed costs, which cannot be dealt with due to the translog utility function. We therefore follow a slightly different approach which is computationally more convenient: we add fixed revenues of not working $(F R)$ to the income at zero hours of work. ${ }^{5}$ Thus $U\left(y_{0}, l_{0}\right)$ is replaced by $U\left(y_{0}+F R, l_{0}\right)$. $F R$ is specified as follows:

$$
F R=\delta^{\prime} t
$$

$t$ is a vector of exogenous variables, $\delta$ a vector of parameters. ${ }^{6}$ Positive fixed revenues increase the probability of nonworking by increasing the utility of nonparticipation (since utility increases with income). The fixed revenues are fully incorporated in the structural model. For example, an increase in wages will increase $U\left(y_{j}, l_{j}\right)$ for $j>0$, but does not change the utility of not working, and thus increases the participation rate. Therefore, the effects of wage (or tax, benefits, etc.) changes on participation can be easily analyzed in this framework. Compared with the model conditional on participation (see, for example, Blundell, 1987), this is an important advantage for policy analysis.

\section{Estimation}

For estimating the structural labour supply model, we use a simulated maximum likelihood method approach. Other than van Soest (1995), we incorporate the wage equation (8) and estimate it simultaneously with the labour supply model. The standard model, without random preferences and

\footnotetext{
${ }^{5} \mathrm{~A}$ difference between fixed costs of working and fixed revenues of not working is induced by the income effect. If the same regressors were used in the fixed costs and the utility function, this would just be a matter of functional form. An alternative way to avoid problems with negative income values would be to define fixed costs as a percentage of income (as in Euwals and van Soest, 1999), or to work with a quadratic rather than a log quadratic utility function. The former does not seem very natural from an economic point of view, the latter has the drawback that the constraint that utility must increase with income becomes binding.

${ }^{6}$ We also estimated models with a random error term added to the right hand side of (9). In all our specifications however, the estimated standard deviation of it appeared to be close to zero, with standard error larger than its estimate. Even if such an error term is included, as long as such an error term is independent of other error terms, the model is identified without imposing exclusion restrictions on the regressors $x$ in (2) or on $t$ in (9). The intuition behind this is the same as in the censored regression model with unobserved censoring threshold (see Nelson, 1977).
} 
with observed wage rates only, could be estimated by maximum likelihood. The likelihood contribution would be given by equation (7). For unobserved wages, the error terms in the wage equation $\left(\epsilon^{w}\right)$ have to be integrated out using (8). When random preferences are considered, an additional error term $\left(\epsilon^{r}\right)$ has to be integrated out as well. This requires two dimensional numerical integration. We denote the probability of working $h_{j}$ hours conditional on $\epsilon^{r}$ and the wage rate $w^{7}$ by

$$
\operatorname{Pr}\left[h=h_{j} \mid w, \epsilon^{r}\right] \quad(j=1, \ldots, m),
$$

This probability directly follows from (7), using (1), (2) and (9) to obtain the values of $U\left(y_{i}, l_{i}\right)$. The exact likelihood contribution for someone observed to work $h^{o}$ hours with observed gross wage rate $w^{o}$ is then given by

$$
L=\left\{\int_{-\infty}^{+\infty} \operatorname{Pr}\left[h=h^{o} \mid w^{o}, \epsilon^{r}\right] f_{1}\left(\epsilon^{r} \mid w^{o}\right) \mathrm{d} \epsilon^{r}\right\} f\left(w^{o}\right),
$$

If the wage rate is not observed (usually implying that $h^{o}=0$ ), the exact likelihood is

$$
L=\int_{-\infty}^{+\infty} \int_{-\infty}^{+\infty} \operatorname{Pr}\left[h=h^{o} \mid w, \epsilon^{r}\right] f_{1}\left(\epsilon^{r} \mid w\right) \mathrm{d} \epsilon^{r} f(w) \mathrm{d} w,
$$

Here $f_{1}$ is the conditional density of $\epsilon^{r}$ given $w$ (or given $\epsilon^{w}$, the error term in (8), and $f(w)$ is the density of the wage rate (or of $\epsilon^{w}$ ). Both are univariate normal densities.

To solve the numerical integration problem, we approximate the integral by a simulated mean: for each individual, we take $R$ drawings from the distribution of the error terms $\left(\epsilon^{r}\right.$ in (11) or $\epsilon^{r}$ and $\epsilon^{w}$ in (12)), and compute the average of the $R$ likelihood values conditional on the drawn errors. The integral (12) can thus be approximated by

$$
L=\frac{1}{R} \sum_{q=1}^{R} \operatorname{Pr}\left[h=h^{o} \mid w_{q}, \epsilon_{q}^{r}\right]
$$

where $w_{q}=\pi^{\prime} z+\epsilon_{q}^{w}$, and $\left(w_{q}, \epsilon_{q}^{r}\right)(q=1, \ldots, R)$ are based upon independent draws from the distribution of $\left(\epsilon^{w}, \epsilon^{r}\right)$. Similarly, the integral (11) can be replaced by

\footnotetext{
${ }^{7}$ Throughout, we condition on earnings of the husband and children, and other exogenous explanatory variables $x, z$ and $t$. These are suppressed in our notation.
} 


$$
L=\frac{1}{R} \sum_{q=1}^{R} \operatorname{Pr}\left[h=h^{o} \mid w^{0}, \epsilon_{q}^{r}\right] f\left(w^{0}\right)
$$

The resulting estimator is inconsistent for fixed $R$, but will be consistent if $R$ tends to infinity with the number of observations $(n)$. If $n^{1 / 2} / R \rightarrow 0$ and with independent drawings across observations, the method is asymptotically equivalent to maximum likelihood, see Lee (1992) or Gourieroux and Monfort (1993).

The estimation method also makes clear why the error terms $\epsilon_{j}$ in (6) are useful. These error terms make $\operatorname{Pr}\left[h=h^{o} \mid w, \epsilon^{r}\right]$ a smooth nonzero function of the parameters. The extreme value error terms facilitate estimation and play the role of a kernel smoother, as described in McFadden (1989). ${ }^{8}$ See also Hajivassiliou and Ruud (1994) who compare the properties of smooth and non-smooth simulated maximum likelihood estimators. In terms of the discrete choice literature, the model can be called a generalized mixed logit model. Brownstone and Train (1999) compare mixed logit models with pure probit models in which all errors are normally distributed. Estimation of the probit models is computationally harder, but feasible using the GHK simulator. The results of Brownstone and Train suggest that the choice between logit and probit errors does not substantially affect the estimates of the parameters of interest.

\section{Data}

The data we use are drawn from Mexico's Urban Employment Survey (Encuesta Nacional de Empleo Urbano, second quarter of 1992), conducted by Instituto Nacional de Estadistica, Geografia e Informatica (INEGI, Mexico's National Statistics Institute) in 32 Mexican cities. The survey is the only quarterly household survey in Mexico and the source of official open unemployment rates. It provides detailed information on the economic activities of all the household members older than twelve years of age, such as employment status, employment conditions, working hours, labour income, characteristics of the workplace, etc., but no information on nonlabour income. It

\footnotetext{
${ }^{8}$ The computational convenience of the extreme value error terms (often combined with error terms with another distribution such as the normal) has been exploited earlier in the context of discrete choice dynamic programming and panel data models (see Berkovec and Stern, 1991, and Stern, 1995).
} 
has been used for unemployment analysis in urban Mexico, by, for example, Fleck and Sorrentino (1994). It has been used by Villagomez (1996) for an analysis of the labour market in Mexico City, with focus on the impact of segmentation on the individual's labour supply. In this paper, we use the sub-sample for married couples in Mexico City in which each partner is less than 65 years old and the husband is employed. This gives observations on 3008 households. Some observations, however, are incomplete. 302 observations have no information on the husband's income, 173 observations have no information on the wife's income, in 3 observations both "husband" and wife are females, in 20 observations the wife is retired or a full-time student. After eliminating these observations, we get a sample of 2510 families. The means and standard deviations of the variables used in the analysis are presented in Table 1.

In 26 percent of all households, the wife has a paid job. Figure 1 gives the distribution of working hours for the working wives. 31 percent of them work less than 30 hours per week (compared to only 8.6 percent of their husbands). Figure 2 gives the distribution of the working wives' after-tax wage rates. The mean and median of wage rate are 7.17 and 4.89 pesos, respectively, while the figures for the husbands are 7.58 and 4.44 pesos, respectively.

To get an idea about the age pattern of the female participation rate, we plot a nonparametric estimate of the participation probability as a function of age in Figure 3. The pattern is inversely U-shaped. Women of about 30 years of age work most often. Figure 4 shows the pattern for different subsamples. The figures do not reveal a clear relation between participation and the presence of children or other adult females in the household if age is controlled for. A model with more structure seems needed for this.

In our final sample, $83.1 \%$ are nuclear families, consisting of no other persons than head, partner, and their children. We use various indicators of family structure in the labour supply model. The variable adults counts the number of adults including head, partner, their children of age at least 12 (1.18 per household, on average), and other household member of age at least 12 (0.22 per household, on average). Child12 counts the number of children younger than 12. ofemale is a dummy for the presence of other adult female(s) in the family. This usually refers to daughters older than 11, of whom there are, on average, 0.59 per household, and sometimes to other female household members older than 11 ( 0.14 per household, on average). Finally, the interaction dummy chdofem indicates whether there are adult 
females other than the mother who could take care of the young children. ${ }^{9}$ $48 \%$ of the families in our sample have young children (age $\leq 12$ ), $26 \%$ of these also have adult females other than the mother. Adult females other than the mother are present in about 35 percent of all families in the total sample.

Table 2 gives the means of some variables for several subsamples. The low educated group refers to females with at most six years of schooling, and the high educated group are all the others. Compared to those with lower education level, highly educated individuals tend to be younger, participate more often, and, given participation, have higher wage rates and work more hours. Their husbands' incomes are higher, possibly because the husband also tends to have high education level. Wives with high education level have more young children but fewer adult females in the household. This may be due to the age differential, however.

In families with children, the wives participate more often if there is another adult female. Given participation however, they work fewer hours than the wives in other families. Comparing all wives with children with those without children, we find that the former participate more often. On the other hand, conditional on participation, wives without children work more hours. The differences are small, however.

Many of these results suggest that the effects of family composition on participation and hours worked are different. In the structural model, this can be allowed for by making preferences as well as fixed costs of working (or fixed revenues of not working) dependent on family composition variables.

In the empirical literature on structural labour supply models, the role of progressive income taxes is often emphasized (see Hausman, 1985, for example). For the current study on Mexico, however, the relevance of explicitly including the income tax in the analysis is doubtful. Mexico's tax system is described in the appendix. The relation between before and after tax incomes is almost linear. Moreover, nearly $36 \%$ of the workers in the sample work in the informal sector, where income taxes are hardly collected. Finally, although the situation has improved, tax evasion is still common due to poor tax collection, long collection lags, and high inflation rates. In 1991, only 17.1 million individuals registered tax payers in a population of about 86 million (Aspe Armella, 1992), and total tax income was 15.6\% of GDP.

\footnotetext{
${ }^{9}$ We also replaced chdofem with a dummy for the presence of both daughter $\geq 12$ and a child $\leq 12$. This gave very similar results.
} 
Individual income tax is just a small part of this, amounting to $2.0 \%$ of GDP in 1990 (OECD Economic Surveys, 1992). We will use only after-tax income in the benchmark model, ignoring the nonlinearity in the income tax, and discuss a model which incorporates the features of the income tax system in our sensitivity analysis. The survey contains information on after-tax earnings per week. Log after-tax hourly wages are computed from this and hours worked per week. In the model with income tax, before-tax wage rates are recovered from the after-tax income using the details of the tax brackets. It is assumed that before tax wage rates do not vary with hours worked. In the benchmark model, it is assumed that after-tax wage rates do not vary with hours worked.

The husband's earnings, together with earnings of unmarried children, are considered as the wife's nonlabour income. In the models we present, we do not include income of other family members. We included this as a separate explanatory variable, but found it was insignificant.

\section{Estimation Results}

We present the estimation results for three labour supply models with fixed costs in Table 3. In the first model (Model I), wage equation error terms are assumed to be uncorrelated with random preferences, while the other two models (Models II and III) allow for correlation. The SML estimates of all models are based upon $\mathrm{R}=20$ draws per household. We use $I L=10$ and $m=8$ for Model I and II, and $I L=4$ and $m=19$ for Model III. Model II is our benchmark model, for which we will discuss the results in detail. The results for the other two models are presented to show how sensitive the results are for allowing for correlation (model I) and for the choice of the number of points in the budget set (model III). In the sensitivity analysis in the next section, we will compare the resulting elasticities with some other alternative models. The estimates of Model II and III appear to be very similar, but different from those of Model I. The estimated utility function is increasing in income in more than $98 \%$ of all sample points for all three models. ${ }^{10}$

The signs of the parameters determine the way in which characteristics affect preferences. A positive $\beta_{2 k}$ implies a positive effect of $x_{k}$ on the marginal

\footnotetext{
${ }^{10}$ The numbers of exceptions are 45, 17, and 29 (out of 2510 observations) in Models I, II and III, respectively.
} 
utility of leisure, and a negative effect on labour supply. A positive parameter in the fixed revenues equation indicates that the corresponding variable has a negative impact on participation. In all three models, coefficients of age terms appear to be insignificant for preferences, but significant in the fixed revenues equation. The coefficients for the number of young children are separately insignificant but Wald tests show that they are jointly significant (at the $5 \%$ level) in models II and III. The number of adults plays opposite roles in labour supply and labour force participation: we find a positive coefficient in $b_{2}$ and a negative coefficient in fixed revenues. The number of elderly and disabled people is not significant. ${ }^{11}$ The joint presence of young children and another adult female decreases fixed costs of working, thus increasing labour force participation of mothers. It does not affect preferences significantly, implying that it will not change labour supply conditional on participation.

To show the effects of family structure, we have drawn some labour supply curves in figures 5-7. These are based on simulations using Model II, and take account of fixed revenues and error terms. Presented are, as a function of wage rate and family characteristics, expected numbers of hours worked, with the expectation taken over the error terms in the model other than $\epsilon^{w}$. The wife's age is set to 35 years. Figure 5 presents labour supply curves for families including and excluding other adult females. In both families there are 1 child and 4 adults. In the range between 0 and 20 pesos, containing nearly $96 \%$ of all observed wages, the presence of other females increases labour supply of mothers. Figure 6 shows that the more children the wife has, the fewer hours she will work. Figure 7 shows that the number of adults in the family does not have much influence at low wage levels, but at high wages individuals in large families work more. This is because, at low wages, the two opposite effects on preferences and fixed revenues cancel out, while at high wages levels, the positive effect via preferences on labour supply dominates. Overall, the three figures suggest that the impact of family composition be quite limited, although it is statistically significant.

The significant estimates of $\rho$ in Models II and III indicate that the error in the wage equation $\left(\epsilon^{w}\right)$ and the random preference term $\left(\epsilon^{r}\right)$ are correlated. Their positive signs imply a positive correlation between the two. In the model, this reflects a positive correlation between unobserved heterogeneity

\footnotetext{
${ }^{11}$ Although this is not necessary for identification, we excluded this variable from the preferences specification. Since the variable hardly plays a role in the fixed revenues either, we do not expect the results would change if the variable had not been included at all.
} 
in wages and unobserved heterogeneity in the marginal utility of leisure. This is a somewhat unexpected result, since we would expect that the more productive people also tend to have a larger preference for work, i.e. a lower marginal utility of leisure. An alternative, perhaps more plausible, interpretation is that the positive correlation reflects measurement error in the observed hourly wages. ${ }^{12}$ This is not explicitly allowed for in our model, however: we assume that the wage rate including the error term drives the labour supply decision.

Due to the complex structure of the model, the parameters $A_{i j}$ are hard to interpret. In Figure 8, we draw some indifference curves in the $(y, h)$ plane for families with one child and four adults, including one other female. Age is set to 35. For other types of families, the figures are similar. The figure based upon Model II. Error terms and fixed costs are not taken into account. Utility levels increase from the dashed to the solid line. The curves have the expected convex shape. At low hours, many curves are almost flat, indicating that nobody (ignoring error terms) would want to work part-time. This can explain why relatively few part-time jobs are observed in the data. Together with fixed revenues, random preferences, etc., the shape of the indifference curves determines the sensitivity of labour supply for changes in wages, other income, etc.. This will be discussed in next section.

\section{Simulations}

Using simulations, we first examine the goodness of fit of the models, and then analyze the sensitivity of average labour supply and participation with respect to wage rate and other income. The third purpose of the simulations is to compare the different specifications of the model. In particular, we study the relevance of incorporating the tax system. The simulated hours per individual are the "expected hours," computed as a probability weighted sum of hours levels. From these, we compute average values for the whole sample and for several subsamples. Simulated hours given participation are the ratios of hours worked and the probability of participation. Wage and

\footnotetext{
${ }^{12}$ In a loglinear model for hours worked, it is straightforward to show that correlation between $\epsilon^{w}$ and $\epsilon^{r}$ would perfectly correct for a measurement error in $w$ independent of $h$. If the effect of wages on labour supply is positive, this would lead to a negative correlation between wage equation and labour supply equation errors. In the current nonlinear model, the correlation we find can be seen as a first order approximation for this.
} 
income elasticities are derived by increasing all wage rates or other incomes by $1 \%$ and calculating the percentage change of average hours.

Table 4 presents means of observed and simulated hours (given participation) and participation rates for Model II. We split the sample according to the women's education level, and each group was further split by family type. The model fits the data quite well in terms of the predicted mean hours worked and participation rates for the whole sample. The model also predicts a large part of the difference between participation rates of those with high and low education level, although there are no education variables in the structural model, and education enters through the wage rates only. Differences between average hours worked of working women in the various subsamples are small, and they are not captured by the model. Similar results (not presented) are found for Models I and III.

Simulated elasticities for Model II are presented in Table 5 for the full sample and in Table 6 for some sub-samples. The numbers are point estimates. By repeating the simulations for a large number of draws from the estimated asymptotic distribution of the parameter estimates, we also calculated $95 \%$ confidence intervals (Table 5) or standard errors (Table 6). As can be seen in Table 5, a rise of $1 \%$ in all wage rates would lead to a rise of average working hours by $0.87 \%$, while participation would increase by $0.75 \%$. If other income (i.e. husband's and unmarried children's income) increases by $1 \%$, average working hours would fall by $0.17 \%$, and participation would decrease by $0.10 \%$. The confidence intervals show, for example, that the other income elasticity of hours worked is significantly negative, though not very precisely determined. It should be noted that many different elasticities are used in the empirical literature, limiting the value of comparisons. For example, many studies consider the elasticity of the average household, or the mean of the elasticities of all households in the sample. We consider the elasticity of average hours worked, which seems the most interesting elasticity from a policy point of view. Moreover, the other income elasticity will depend on what is included in other income, which is largely determined by the data at hand (see Section 3). Finally, our elasticities include the effects on participation, while many empirical studies in the literature focus on workers only, and analyze labour supply elasticities conditional upon participation.

The main conclusion from Table 6 is that the wives who are higher educated are more sensitive to wage changes, but less sensitive to changes of other incomes than the lower educated. For given education level, elasticities do not vary a lot with family composition, and many of these differences are 
insignificant. For the low educated wives, the wage elasticity decreases with the presence of children younger than 12, but for the higher educated wives, the reverse is found. The (absolute value of the) income elasticity increases with the presence of children for both education levels.

We present the simulation results for the whole sample of various alternative specifications in Table 7 . The first row repeats the results of the benchmark model, Model II. In the second row, the simulated maximum likelihood procedure is based upon $R=30$ instead of $R=20$ draws per observation. Rows 3, 5 and 6 use models with more points in the choice set and smaller hours intervals (multiples of 4, 2, and 1 hours per week, versus 10 hours in model II). Row 4 uses the same model as row 3 , but with $R=30$ instead of $R=20$. The table shows that in terms of predicted hours and participation, these specifications give similar results as the benchmark model. In terms of elasticities, the results for $R=20$ and $R=30$ draws are also very similar. This suggests that for 20 draws already, the simulated maximum likelihood results are a good approximation to exact maximum likelihood, in line with results of van Soest (1995). The wage elasticities vary somewhat with the number of points in the choice set, with smaller values in the model with a finer hours grid, but even the smallest values are above the lower bound of the $95 \%$ confidence intervals according to the benchmark model (see Table $5)$. Thus the elasticities we obtain are reasonably robust to the choice of hours grid, although there seems to be some tendency that choosing fewer points leads to higher wage and income elasticities of hours worked.

The seventh row of Table 7 presents the simulation results of Model I. In terms of average working hours and participation rates, Model I performs similarly as Model II; the assumption of no correlation between wage equation error and random preferences does not matter much for goodness of fit. But compared to Model II, the wage elasticities are smaller.

The final row in Table 7 shows the results when we incorporate the progressive income tax system (Model III). The estimated elasticities are very close to those in the benchmark model, confirming that the nonlinearity of the Mexican income tax system hardly plays a role.

To test formally for model misspecification, we use the chi-square goodness of fit tests introduced by Andrews (1988). These are generalizations of the traditional Pearson chi-square tests for the multinomial model. They are based upon partitioning the sample space into a given number of cells $J$, and comparing sample frequencies with probabilities predicted by the model. In our case the test statistic is based upon the SML estimates, and the test 
statistic can be computed straightforwardly. Let $A$ be the $n \times J$ matrix with the differences between observed and predicted cell probabilities per observation, where $n$ is the number of observations. ${ }^{13}$ Let $B$ be the $n \times K$ matrix of scores, where $K$ is the number of estimated parameters, and let $C$ be the matrix $[A \mid B]$. The test statistic is then equal to the explained sum of squares of the regression of an $n \times 1$ vector of ones on the columns of $C$. If the $J$ cells are constructed as products of a partition of the covariates space $(X)$ into $G$ cells, and the space of endogenous variables (working hours, $H$ ), then under the null of a correct specification, the test statistic follows a chi-square distribution with $J-G$ degrees of freedom.

We computed eight test statistics based on different partitions of $X \times H$. For $X$, we use four partitions: a) no partitioning, b) two education categories (low level vs. high level), c) two family size categories (small vs. large families), d) three types of families (with children and other females, with children but no other females, without children). For $\mathrm{H}$ we use two partitions: a) a partition into eight hours categories, and b) a partition into the three categories not working, working part-time, and working full-time. The results are presented in Table 8 . The tests reject the null-hypothesis of no misspecification. This shows that the model does not perfectly reproduce participation rates and hours worked in the data. ${ }^{14}$ The fact that the model specification is formally rejected by the data is not uncommon in the literature. As far as we know, in the few studies that explicitly test for this, the result is the same (Magnac, 1991, Pradhan and van Soest, 1997).

\section{Conclusions}

We have analyzed labour supply of married women in Mexico City, emphasizing the influence of family structure. We used a static structural neoclassical model, extending the model of van Soest (1995). Fixed revenues of not working are taken into account, and are found to be positive for all the ob-

\footnotetext{
${ }^{13}$ The observed probability is one if the individual belongs to the cell and zero otherwise. The predicted probability is based upon the parameters estimates, and conditional on the covariates.

${ }^{14} \mathrm{~A}$ closer look at the test results reveals that the columns of $A$ and $B$ are almost collinear. The explained sum of squares remains small if either the columns of $A$ or the columns of $b$ are included, but explodes when they are used simultaneously. The intuitive interpretation is that the model fit may be reasonable, but that the flexibility of the model should lead to an even better fit if the specification was correct.
} 
servations. Also incorporated are random preferences, error terms in wages of nonworkers, and correlation between these two types of error terms.

We find that the overall effects of family structure on labour supply are limited although significant, with some opposite effects through fixed revenues of not working and preferences. Nevertheless, in the range where most observed wages are found, the presence of another female increases labour supply of mothers with young children. These results are robust across the different specifications. The estimates for alternative specifications (not presented in the paper) not only have same signs but also appear to be very similar in magnitude and significance level.

The married women's labour supply elasticities we find are in line with those in the literature (although these are often defined and computed in different ways): in our benchmark model, the uncompensated wage elasticity of average hours worked for the total sample is 0.87 , while the other income elasticity is -0.17 . These elasticities are based upon a discrete choice set, where it is assumed that each married females chooses between working 0 hours, 10 hours, 20 hours, ... and 70 hours per week. Increasing the number of choices to multiples of 4, 2 or 1 hour per week, leads to somewhat smaller wage elasticities, and to almost the same income elasticities. These elasticities are never outside the $95 \%$ confidence interval for the elasticities in the benchmark model. On the other hand, ignoring correlation between the error term in the wage equation and the random preference error term, leads to strongly underestimated wage elasticities. 


\section{Appendix: Mexico's income tax system}

Mexico has an individual based income tax system. It is progressive with 8 brackets, which are indexed to inflation. To compensate for the high inflation rate, subsidies are used to reduce the effective marginal rate. The subsidy rates are also progressive. The marginal tax rate ranges from $3 \%$ to $35 \%$, but if subsidies are taken into account, they vary only from $3 \%$ to $17 \%$. Many components of income are tax-exempt, for example, fringe benefits, overtime pay, and social insurance benefits (OECD Economic Surveys, 1992).

In the sample, 545 out of 644 workers fall in the brackets with a marginal rate of $17 \%$ or less. Taking account of the subsidy, their effective marginal rate is at most $8.5 \%$. In Figure A1, the wives' yearly after-tax earnings are plotted against yearly before-tax earnings. The relation is close to linear. Regressing after-tax earnings on before-tax earnings for workers, gives a slope coefficient of about 0.82 (with standard error 0.002), and an R2 of 0.99 . 


\section{References}

Andrews, Donald W. K. 1988. "Chi-square Diagnostic Tests for Econometric Models - introduction and applications." Journal of Econometrics 37:135-156.

Aspe Armella, Pedro. 1992. "Tax Policy in Mexico." Bulletin for international Fiscal Documentation: Official Organ of the International Fiscal Association 46:414-416.

Berkovec, James, and Steven Stern. 1991. "Job exit behavior of older men." Econometrica 59:189-210.

Blundell, Richard. 1987. "Econometric approaches to the specification of life-cycle labour supply and commodity demand behaviour." Econometric reviews 6:103-165.

Brownstone, David and Kenneth Train. 1999. "Forecasting new product penetration with flexible substitution patterns." Journal of Econometrics 89:109-129.

Callan, Tim and Arthur van Soest. 1995. "Family Labour Supply and Taxes in Ireland." Working paper, Tilburg University.

CBS. 1993. "Arbeidsdeelname in Nederland vanaf 1961 in Internationaal Perspectief." Supplement Sociaal-economische Maandstatistiek 1993(2):13-19.

Euwals, Rob and Arthur van Soest. 1999. "Desired and Actual Labour Supply of Unmarried Men and women in the Netherlands." Labour Economics 6:95-118.

Fleck, Susan and Constance Sorrentino. 1994. "Employment and Unemployment in Mexico's labour force." Monthly Labour Review 117(11):3-31.

Gourieroux, Christian and Alain Monfort. 1993. "Simulation based inference: A Survey with Special Reference to Panel Data." Journal of Econometrics 59(1-2):5-34.

Hajivassiliou, Vassilis A. and Paul A. Ruud. 1994. "Classical estimation methods for LDV models using simulation." In Handbook of Econometrics, Vol. IV, ed. Robert F. Engle and Daniel L. McFadden, 2384-2443. North-Holland, New York.

Hausman, Jerry A. and Paul A. Ruud. 1984. "Family Labour Supply with Taxes." American Economic Review 74:242-248.

Hausman, Jerry A. 1985. "The Econometrics of nonlinear Budget Sets." Econometrica 42:679-694. 
Lee, Lung-Fei. 1992. "On efficiency of methods of simulated moments and maximum simulated likelihood estimation of discrete response models." Econometric Theory 8:518-552.

Maddala, G.S. 1983. Limited Dependent and Qualitative Variables in Econometrics. Cambridge: Cambridge University Press.

Magnac, Thierry. 1991. "Segmented or Competitive Labour Markets." Econometrica 59:165-187.

McFadden, Daniel L. 1989. "A method of simulated moments for estimation of the multinomial probit without numerical integration." Econometrica 57:995-1026.

Moffitt, Robert A. 1986. "The Econometrics of Piecewise-Linear Budget Constraints." Journal of Business and Economic Statistics 4: 317-328.

Nelson, Forest D. 1977. "Censored regression models with unobserved stochastic censoring thresholds." Journal of Econometrics 6:309-327.

Newman, John L. and Paul J. Gertler. 1994. "Family Productivity, Labour Supply, and Welfare in a Low Income Country." The Journal of Human Resources 29:989-1026.

OECD Economic Surveys. 1992. Mexico. Paris: OECD publications.

Pradhan, Menno and Arthur van Soest. 1997. "Household Labour Supply in Urban Areas of Bolivia." The Review of Economics and Statistics 74:300-310.

Stern, Steven. 1995. "Estimating family long-term care decisions in the presence of endogenous child characteristics." The Journal of Human Resources 30:551-580.

Tienda, Marta and Jennifer Glass. 1985. "Household Structure and Labour Force Participation of Black, Hispanic, and White Mothers." Demography 22:381-394.

Van Soest, Arthur. 1995. "Structural Models of Family Labour Supply -A Discrete Choice Approach." The Journal of Human Resources 30:63-88.

Villagomez, Elizabeth (1996), "Informal Markets: A Model of Household Labour Supply." Working paper, Universidad de Alcala de Henares.

Wong, Rebecca and Ruth E. Levine. 1992. "The Effect of House- 
hold Structure on Women's Economic Activity and Fertility: Evidence from Recent Mothers in Urban Mexico." Economic Development and Cultural Change 41:89-102. 
Table 1. Variable Definitions and Sample Statistics

\begin{tabular}{|c|c|c|c|}
\hline Variable & Definition & Mean & Std. Dev. \\
\hline age & age of the individual & 35.6 & 10.0 \\
\hline age2 & age squared & 1368 & 776 \\
\hline hour & working hours & 8.86 & 16.7 \\
\hline dnosch & dummy no formal schooling & 0.049 & \\
\hline dbasic & dummy $1-6$ years education & 0.428 & \\
\hline djunior & dummy $7-9$ years education & 0.187 & \\
\hline dsenior & dummy $10-12$ years education & 0.048 & \\
\hline dcollege & dummy university education & 0.078 & \\
\hline dtechb & $\begin{array}{l}\text { dummy vocational education } \\
\text { plus } 6 \text { years education }\end{array}$ & 0.041 & \\
\hline dtechj & $\begin{array}{l}\text { dummy vocational education } \\
\text { plus } 9 \text { years education }\end{array}$ & 0.160 & \\
\hline dtechs & $\begin{array}{l}\text { dummy vocational education } \\
\text { plus } 12 \text { years education }\end{array}$ & 0.010 & \\
\hline finc & $\begin{array}{l}\text { total weekly earnings of the husband } \\
\text { and unmarried children }\end{array}$ & 364.5 (pesos) & 480 \\
\hline othern & weekly earnings of other members & 24.0 (pesos) & 95.6 \\
\hline child12 & $\begin{array}{l}\text { No. of children of the head } \\
\text { of household aged } 12 \text { or less }\end{array}$ & 0.876 & 1.09 \\
\hline adult & number of adults (older than 12) & 3.40 & 1.67 \\
\hline ofemale & dummy presence of other female adult & 0.353 & \\
\hline chdofem & $\begin{array}{l}\text { dummy presence of both other } \\
\text { adult female and young child }\end{array}$ & 0.127 & 0.333 \\
\hline eldis & number of elderly and disabled & 0.029 & 0.181 \\
\hline wage & hourly wage (after-tax, pesos) & 7.167 & 7.854 \\
\hline
\end{tabular}

Note: wives of employed family heads only; 2510 observations. 
Table 2. Means by Education Level and Family Composition

\begin{tabular}{l||ll|lll|l}
\hline \hline \multicolumn{1}{c||}{ Variable } & \multicolumn{2}{c|}{ Education } & \multicolumn{3}{c|}{ With Children } & Without \\
& Low & High & Other & No other & All & Children \\
& & & female & female & & \\
\hline obs. & 1199 & 1311 & 319 & 888 & 1207 & 1303 \\
age & 38.3 & 33.1 & 36.8 & 30.0 & 31.8 & 39.1 \\
child12 & 0.78 & 0.96 & 1.66 & 1.88 & 1.82 & 0 \\
adults & 3.91 & 2.94 & 4.29 & 2.36 & 2.87 & 3.90 \\
finc & 280.7 & 441.1 & 333.2 & 3322.3 & 325.2 & 400.9 \\
participation & 18.7 & 32.0 & 32.9 & 24.1 & 26.4 & 24.9 \\
hours $^{*}$ & 33.65 & 35.02 & 32.48 & 34.59 & 33.90 & 35.18 \\
wage $^{*}$ & 4.43 & 8.63 & 5.82 & 7.61 & 7.02 & 7.31 \\
\hline \hline
\end{tabular}

$*$ Workers only 
Table 3. Simulated Maximum Likelihood Estimates

\begin{tabular}{|c|c|c|c|c|c|c|}
\hline & \multicolumn{2}{|c|}{ Model I } & \multicolumn{2}{|c|}{ Model II } & \multicolumn{2}{|c|}{ Model III } \\
\hline \multicolumn{7}{|c|}{ Utility Function (Equation 1): } \\
\hline$\overline{A_{11}}$ & 0.913 & $(0.184)$ & 1.780 & $(0.221)$ & 1.812 & $(0.194)$ \\
\hline$A_{12}$ & 0.706 & $(0.086)$ & 486 & 0 & 0.638 & $0.084)$ \\
\hline$A_{22}$ & -1.864 & $(0.265)$ & -2.045 & $(0.256)$ & -2.161 & $(0.218)$ \\
\hline$b_{1}$ & -14.879 & $(2.017)$ & -21.816 & $(2.314)$ & -23.589 & $(2.070)$ \\
\hline \multicolumn{7}{|c|}{$\beta_{2 k}$ 's in $b_{2}$ (Equation 2): } \\
\hline constant & 4.846 & $(2.938)$ & 8.856 & $(2.950)$ & 7.849 & $(2.742)$ \\
\hline ofem & -0.046 & $(0.370$ & -0.122 & $(0.38$ & 0.089 & $(0.387)$ \\
\hline chdofem & 0.501 & $(0.432)$ & 0.465 & $(0.429)$ & 0.339 & $(0.425)$ \\
\hline age $/ 10^{2}$ & 9.595 & $(10.30)$ & 15.597 & $(10.41)$ & 13.560 & $(10.06)$ \\
\hline age $2 / 10^{4}$ & -9.551 & $(13.0$ & -15.976 & $(13.35)$ & -13.431 & $(12.97)$ \\
\hline child12 & 0.105 & $(0.1$ & 094 & $(0.1$ & 130 & $(0.137)$ \\
\hline adult & -0.207 & $(0.0 \xi$ & -0.215 & $(0.0$ & -0.241 & $(0.100)$ \\
\hline$\sigma^{r}$ & 0.909 & $(0.256$ & 0.821 & $(0.2$ & 0.704 & $(0.248)$ \\
\hline$\rho$ & 0 & & 858 & & .879 & $(0.091)$ \\
\hline \multicolumn{7}{|c|}{ Fixed Revenues (Equation 9): } \\
\hline & 2134.7 & $(663$ & 10 & & .7 & $(259.4)$ \\
\hline ofemale & .549 & $(73.2$ & 15 & $(34$ & 02 & $(37.48)$ \\
\hline chdofem & -186.23 & $(92.6$ & 106 & $(39$ & & $(42.37)$ \\
\hline & -8015.8 & & -3766.0 & & 6.6 & $(1211)$ \\
\hline $\operatorname{age} 2 / 10^{4}$ & 91.3 & $(3870)$ & 03.3 & $(1437)$ & 56.4 & $(1534)$ \\
\hline child12 & 16.047 & $(25.6$ & 6.646 & $(12$. & 4.288 & $(12.88)$ \\
\hline adult & 52.145 & $(25.3$ & 56 & $(9$. & 23.940 & $(11.27)$ \\
\hline eldis & 7.469 & $(82.17)$ & 15.141 & $(38.35$ & .751 & $(41.23)$ \\
\hline \multicolumn{7}{|c|}{ Wage Equation (Equation 8): } \\
\hline constant & 0.010 & $(0.363)$ & 0.600 & $(0.30$ & 0.623 & $(0.309)$ \\
\hline age $/ 10$ & 5.542 & $(1.91$ & 3.478 & $(1.64$ & 3.396 & $(1.645)$ \\
\hline age $2 / 10^{4}$ & -6.389 & $(2.51$ & -3.805 & $(2.166)$ & -3.747 & $(2.169)$ \\
\hline nosch & 0.083 & $(0.11 \%$ & 0.009 & $(0.091$ & 0.013 & $(0.091)$ \\
\hline djuni & 0.196 & $(0.0$ & 87 & & 0.188 & $(0.052)$ \\
\hline dsenic & 443 & $(0.09$ & 10 & $\left(0.0^{\prime}\right.$ & 0.404 & $(0.073)$ \\
\hline & 324 & $(0.0$ & 65 & $(0.0$ & 0.275 & $(0.068)$ \\
\hline dtechj & 0.612 & $(0.0$ & 554 & $(0.049)$ & 0.559 & $(0.049)$ \\
\hline dtech & .751 & (0.19 & 638 & $(0.180)$ & 0.655 & $(0.188)$ \\
\hline$d c o$ & 1.035 & $(0.070$ & 0.856 & $(0.060)$ & 0.862 & $(0.060)$ \\
\hline$\sigma^{w}$ & 0.504 & $(0.016)$ & 0.473 & $(0.012)$ & 0.473 & $(0.012)$ \\
\hline $\log S L^{*}$ & -14 & & -14 & & & \\
\hline
\end{tabular}

Standard errors are in parentheses.

${ }^{*} \log S L$ : simulated log likelihood. 
Table 4. Average Hours Worked and Participation

\begin{tabular}{lrrrrr}
\hline \hline & No. obs. & \multicolumn{2}{c}{ Sample } & \multicolumn{2}{c}{ Model II } \\
\hline Whole sample & 2510 & 34.6 & $(26.5 \%)$ & 33.7 & $(26.4 \%)$ \\
\hline High education & 1311 & 35.0 & $(32.0 \%)$ & 34.0 & $(30.3 \%)$ \\
$\quad$ Family composition & & & & & \\
$\quad$ No child & 584 & 35.4 & $(32.0 \%)$ & 34.4 & $(30.8 \%)$ \\
$\quad$ With children & 727 & 34.7 & $(32.0 \%)$ & 33.6 & $(30.0 \%)$ \\
$\quad$ No other female & 579 & 35.0 & $(30.2 \%)$ & 34.0 & $(27.7 \%)$ \\
$\quad$ With other females & 148 & 33.8 & $(39.2 \%)$ & 32.1 & $(38.3 \%)$ \\
\hline Low education & 1199 & 33.7 & $(18.7 \%)$ & 33.4 & $(22.0 \%)$ \\
Family composition & & & & & \\
$\quad$ No child & 719 & 34.8 & $(19.2 \%)$ & 34.0 & $(21.6 \%)$ \\
$\quad$ With children & 480 & 31.8 & $(17.9 \%)$ & 32.6 & $(22.8 \%)$ \\
$\quad$ No other female & 309 & 32.9 & $(12.6 \%)$ & 33.1 & $(18.8 \%)$ \\
$\quad$ With other females & 171 & 30.9 & $(27.5 \%)$ & 31.5 & $(29.8 \%)$ \\
\hline \hline
\end{tabular}

Percentages in parentheses are participation rates

Sample: sample means and participation rates

Model II: simulated means and participation rates using Model II 
Table 5 Elasticities; Whole Sample

\begin{tabular}{c|rc}
\hline \hline & point estimate & 95\% confidence interval \\
$\epsilon_{h w}$ & 0.867 & {$[0.600,1.089]$} \\
$\epsilon_{h i}$ & -0.166 & {$[-0.264,-0.071]$} \\
$\epsilon_{p w}$ & 0.746 & {$[0.528,0.922]$} \\
$\epsilon_{p i}$ & -0.097 & {$[-0.199,-0.002]$} \\
\hline \hline
\end{tabular}


Table 6 Elasticities for some Subsamples

\begin{tabular}{lcccc}
\hline \hline & $\epsilon_{h w}$ & $\epsilon_{h i}$ & $\epsilon_{p w}$ & $\epsilon_{p i}$ \\
\hline $\begin{array}{l}\text { High education } \\
\text { Composition }\end{array}$ & $1.020(0.13)$ & $-0.153(0.04)$ & $0.873(0.10)$ & $-0.065(0.04)$ \\
No child & $1.003(0.13)$ & $-0.139(0.04)$ & $0.861(0.10)$ & $-0.043(0.04)$ \\
With childern & $1.034(0.13)$ & $-0.165(0.04)$ & $0.883(0.11)$ & $-0.083(0.04)$ \\
No other female & $1.078(0.14)$ & $-0.163(0.05)$ & $0.931(0.11)$ & $-0.076(0.04)$ \\
With other fem. & $0.904(0.12)$ & $-0.173(0.04)$ & $0.746(0.10)$ & $-0.104(0.03)$ \\
\hline Low education & $0.635(0.12)$ & $-0.186(0.06)$ & $0.555(0.10)$ & $-0.146(0.07)$ \\
Composition & & & & \\
No child & $0.652(0.12)$ & $-0.157(0.06)$ & $0.576(0.10)$ & $-0.104(0.07)$ \\
With children & $0.610(0.12)$ & $-0.229(0.06)$ & $0.526(0.10)$ & $-0.205(0.07)$ \\
No other female & $0.602(0.12)$ & $-0.250(0.05)$ & $0.530(0.10)$ & $-0.229(0.08)$ \\
With other fem. & $0.620(0.11)$ & $-0.203(0.06)$ & $0.522(0.09)$ & $-0.178(0.06)$ \\
\hline \hline
\end{tabular}

Standard errors are in parentheses. 
Table 7. Simulation Results of Alternative Model Specifications

\begin{tabular}{lcccccc}
\hline \hline & \multicolumn{3}{c}{ predictions } & \multicolumn{4}{c}{ elasticities } \\
& Hours & Partic. & $\epsilon_{h w}$ & $\epsilon_{h i}$ & $\epsilon_{p w}$ & $\epsilon_{p i}$ \\
\hline Model II & & & & & & \\
$(I L=10, m=8, R=20)$ & 33.7 & $26.4 \%$ & 0.867 & -0.166 & 0.746 & -0.097 \\
$I L=10, m=8, R=30$ & 33.8 & $26.4 \%$ & 0.853 & -0.163 & 0.733 & -0.096 \\
$I L=4, m=19, R=20$ & 33.9 & $26.5 \%$ & 0.802 & -0.165 & 0.685 & -0.071 \\
$I L=4, m=19, R=30$ & 33.9 & $26.6 \%$ & 0.792 & -0.163 & 0.677 & -0.070 \\
$I L=2, m=37, R=20$ & 34.1 & $26.7 \%$ & 0.713 & -0.160 & 0.616 & -0.053 \\
$I L=1, m=73, R=20$ & 34.5 & $26.3 \%$ & 0.604 & -0.152 & 0.531 & -0.037 \\
Model I $(\rho=0)$ & 34.0 & $26.0 \%$ & 0.333 & -0.175 & 0.308 & -0.062 \\
$I L=10, m=8, R=20$, & & & & & & \\
including tax & 33.8 & $26.3 \%$ & 0.847 & -0.174 & 0.732 & -0.105 \\
\hline \hline
\end{tabular}


Table 8. Chi-square tests

\begin{tabular}{cccrr}
\hline \hline Part. of $X$ & Part. of $H$ & Test Stat. & $J-G$ & $\begin{array}{r}\text { Critical value } \\
(\alpha=0.01)\end{array}$ \\
\hline a) & a) & 510 & 7 & 18.5 \\
a) & b) & 118 & 2 & 9.2 \\
b) & a) & 565 & 14 & 29.1 \\
b) & b) & 142 & 4 & 13.3 \\
c) & a) & 520 & 14 & 29.1 \\
c) & b) & 118 & 4 & 13.3 \\
d) & a) & 534 & 22 & 40.3 \\
d) & b) & 122 & 6 & 16.8 \\
\hline \hline
\end{tabular}

* Hours worked given participation

Partions of $X$ : a) No Partition; b) two education categories;

c) two family size categories; d) three family type categories.

Partitions of $H$ : a) eight cells: non-workers, seven cells of workers partitioned according to working hours; b) three cells: 0 hours, between 0 and 40 hours, 40 hours of work or more. 
Figure 1 Distribution of hours worked; workers only

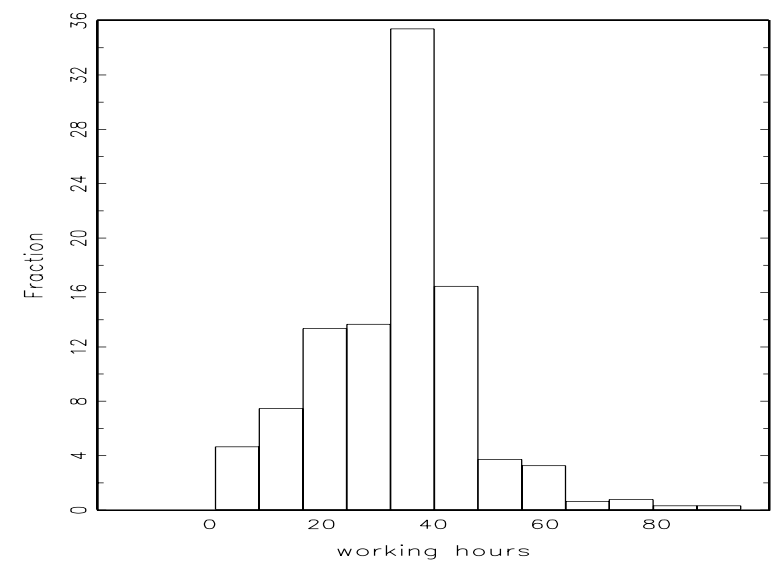

Figure 2. Distribution of after-tax wage rates

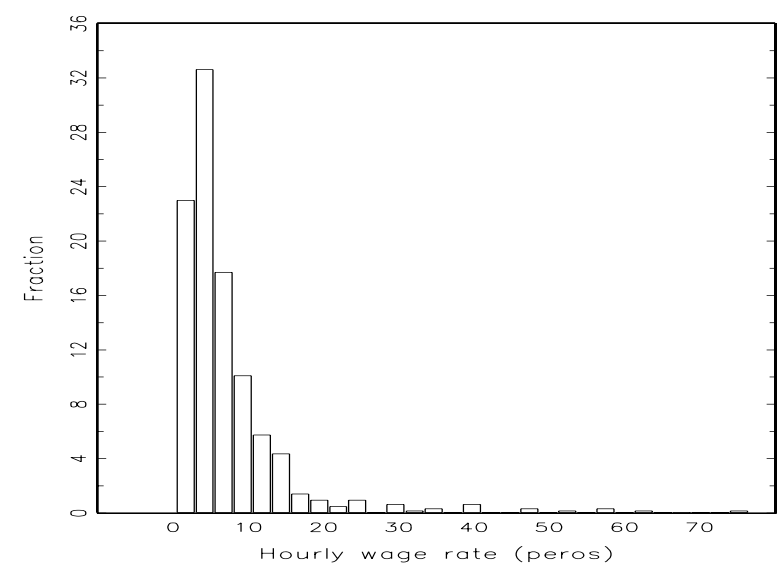


Figure 3. Nonparametric regression of participation rate on age with $95 \%$ uniform confidence interval (bandwidth $=8$ hours)

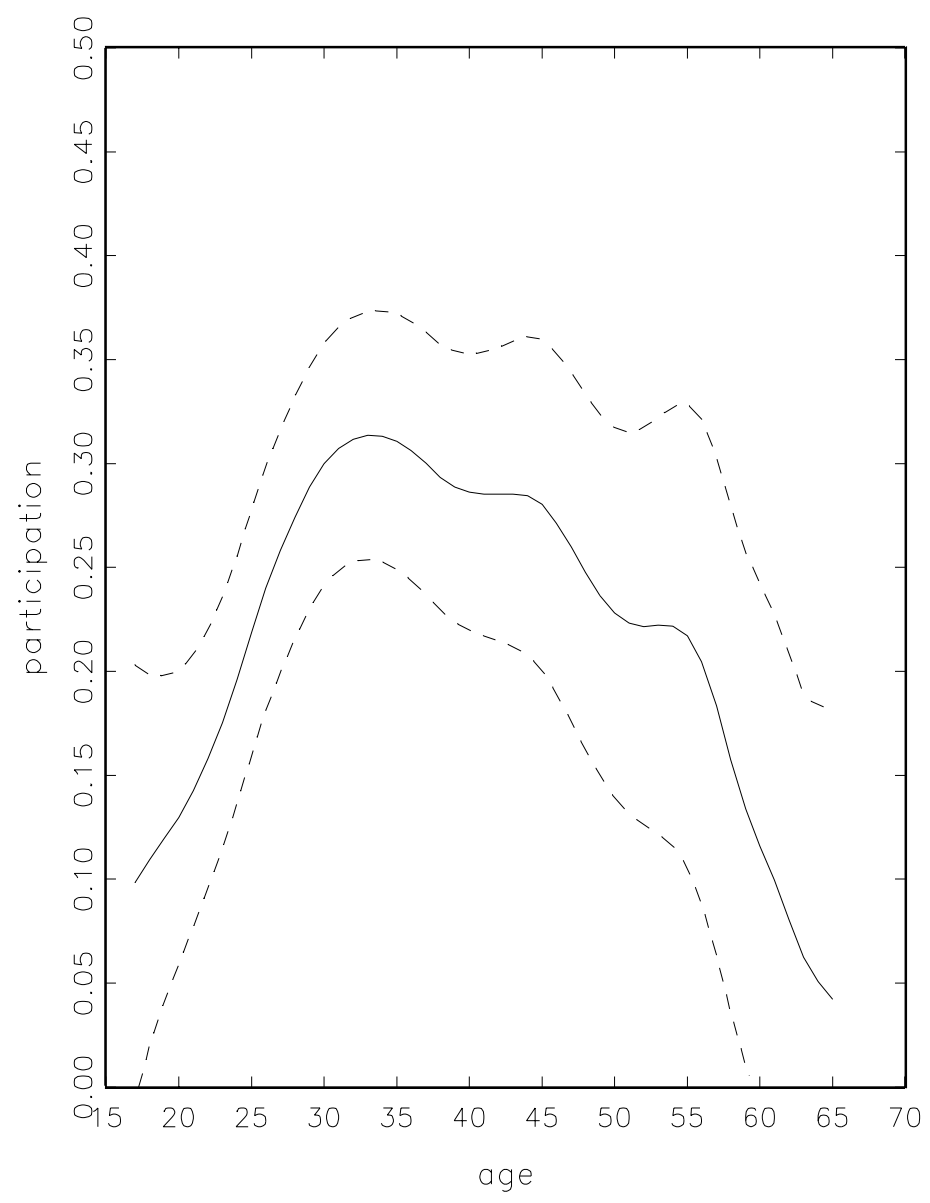


Figure 4. Nonparametric estimates of participation rates on age for subsamples with $95 \%$ uniform confidence intervals
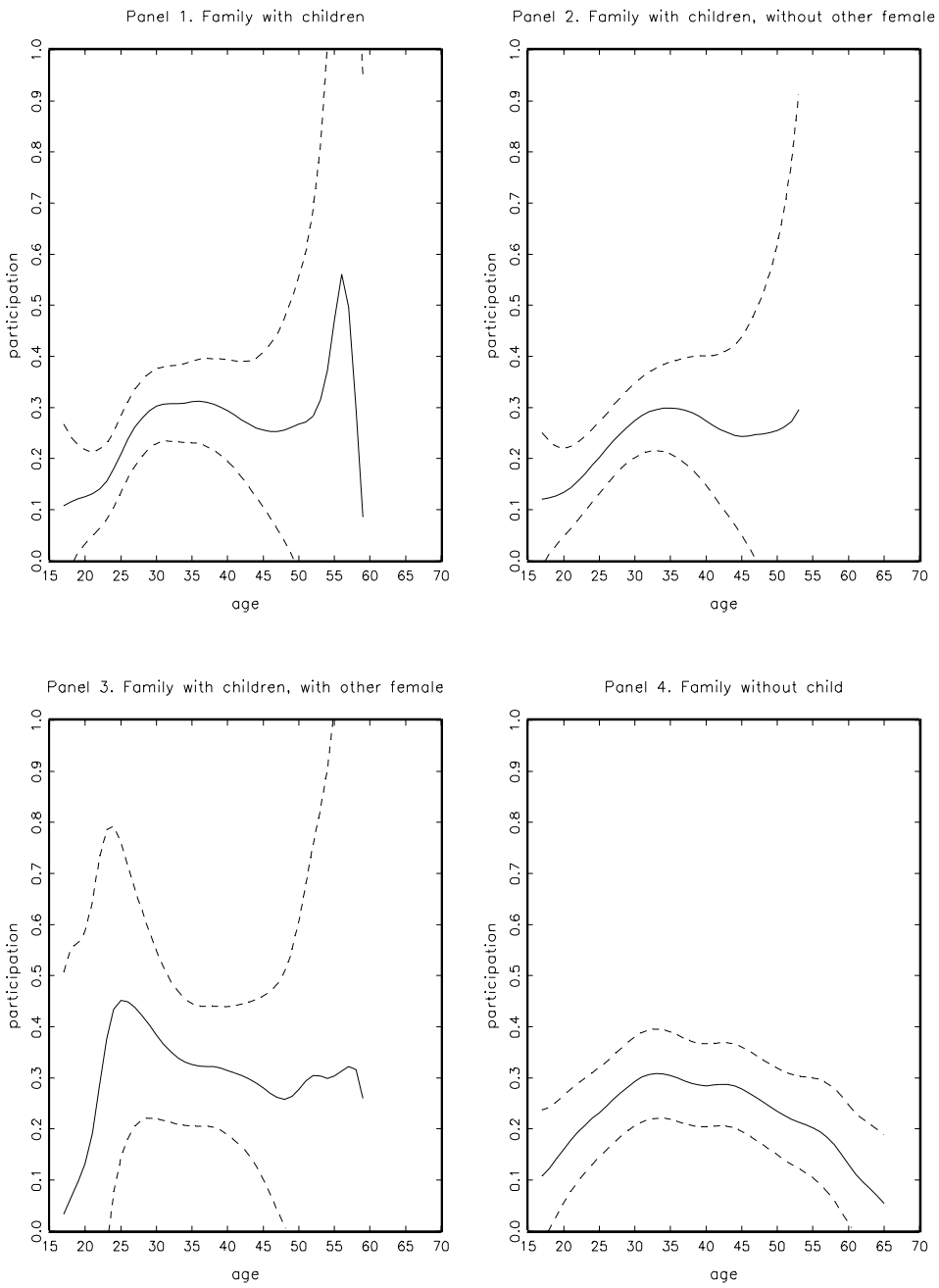
Figure 5. Simulated Labour Supply Curve: Family with one child, four adults, with or without other female

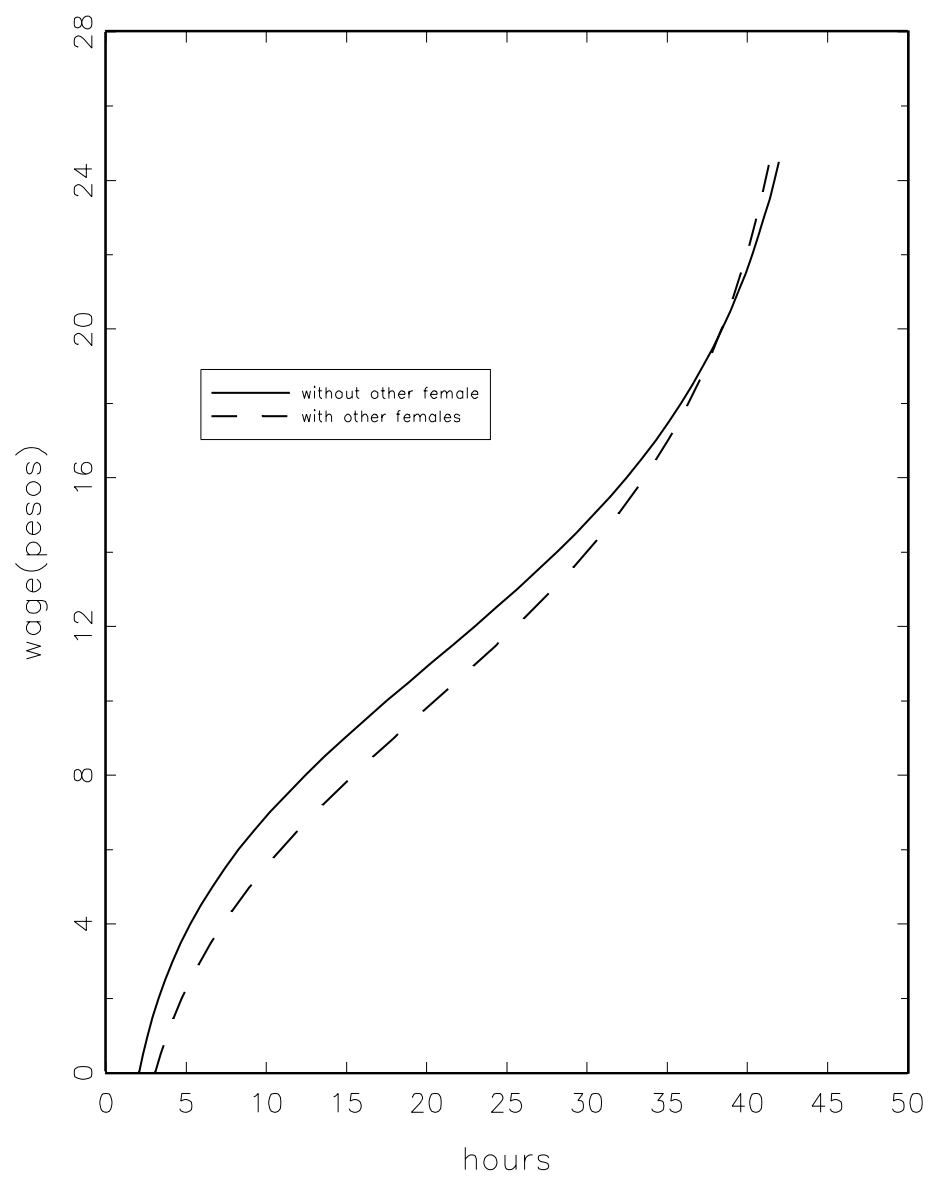


Figure 6. Simulated Labour Supply Curve: Family with zero or two children, four adults, and without other female

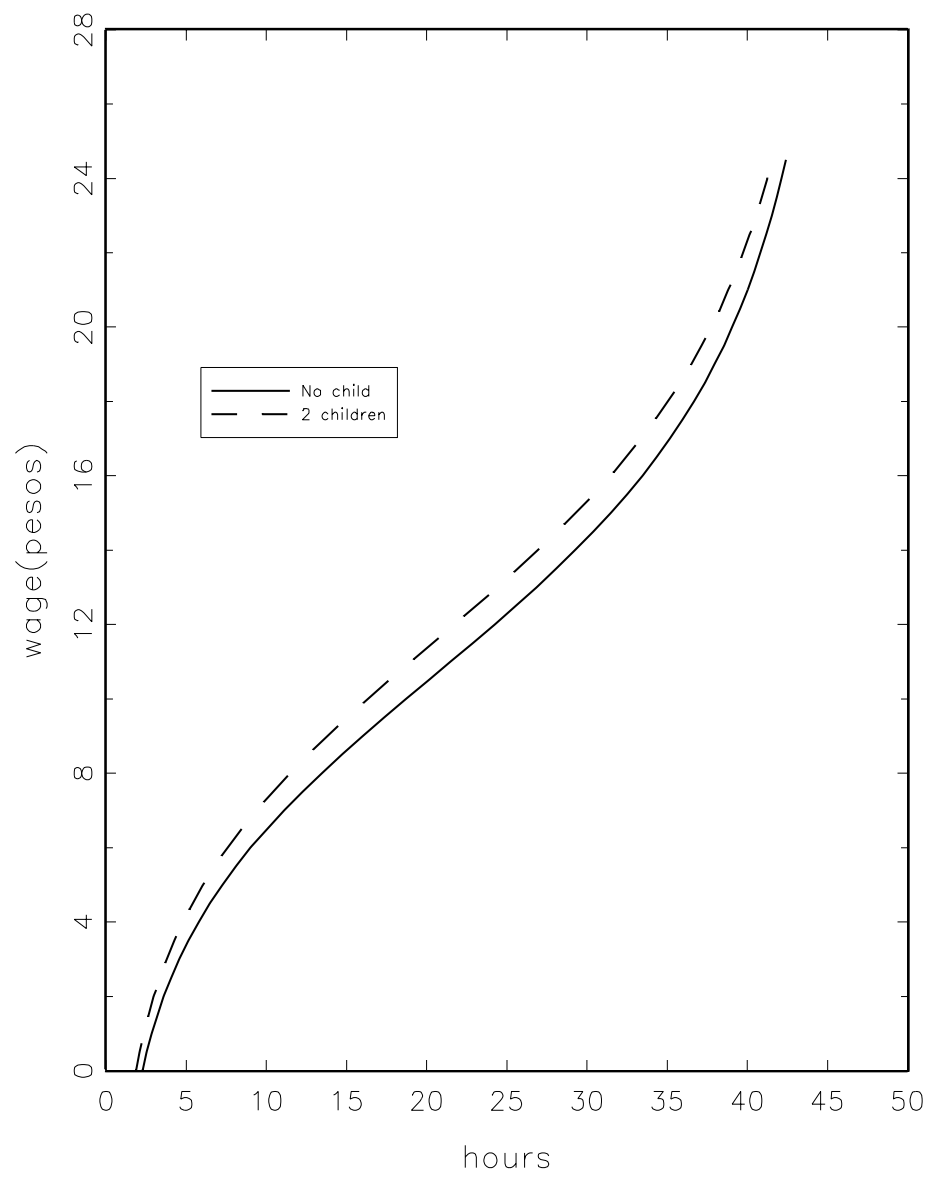


Figure 7. Simulated Labour Supply Curve: Family with one child, without other female, and with three or five adults

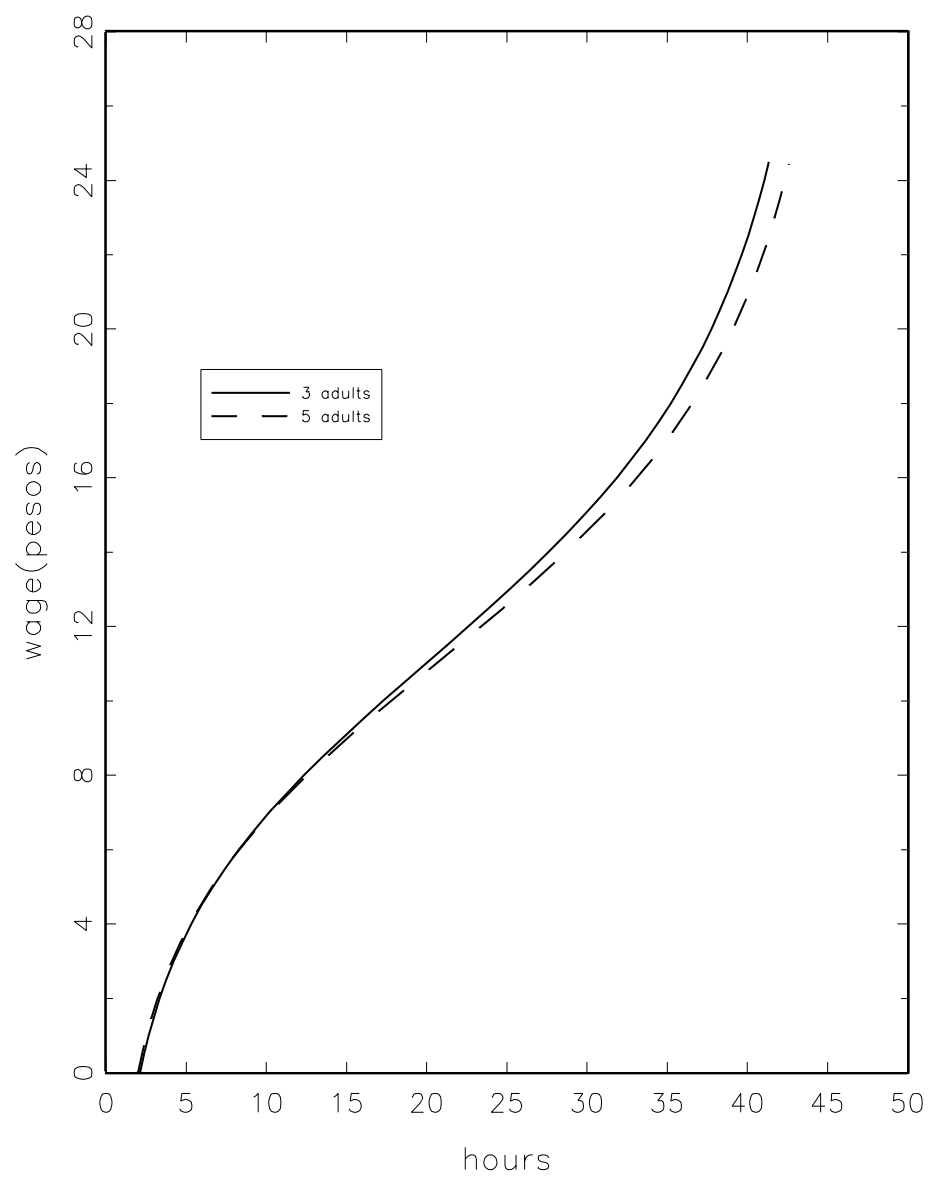


Figure 8. Indifference Curves; Family with one child, four adults and one other female

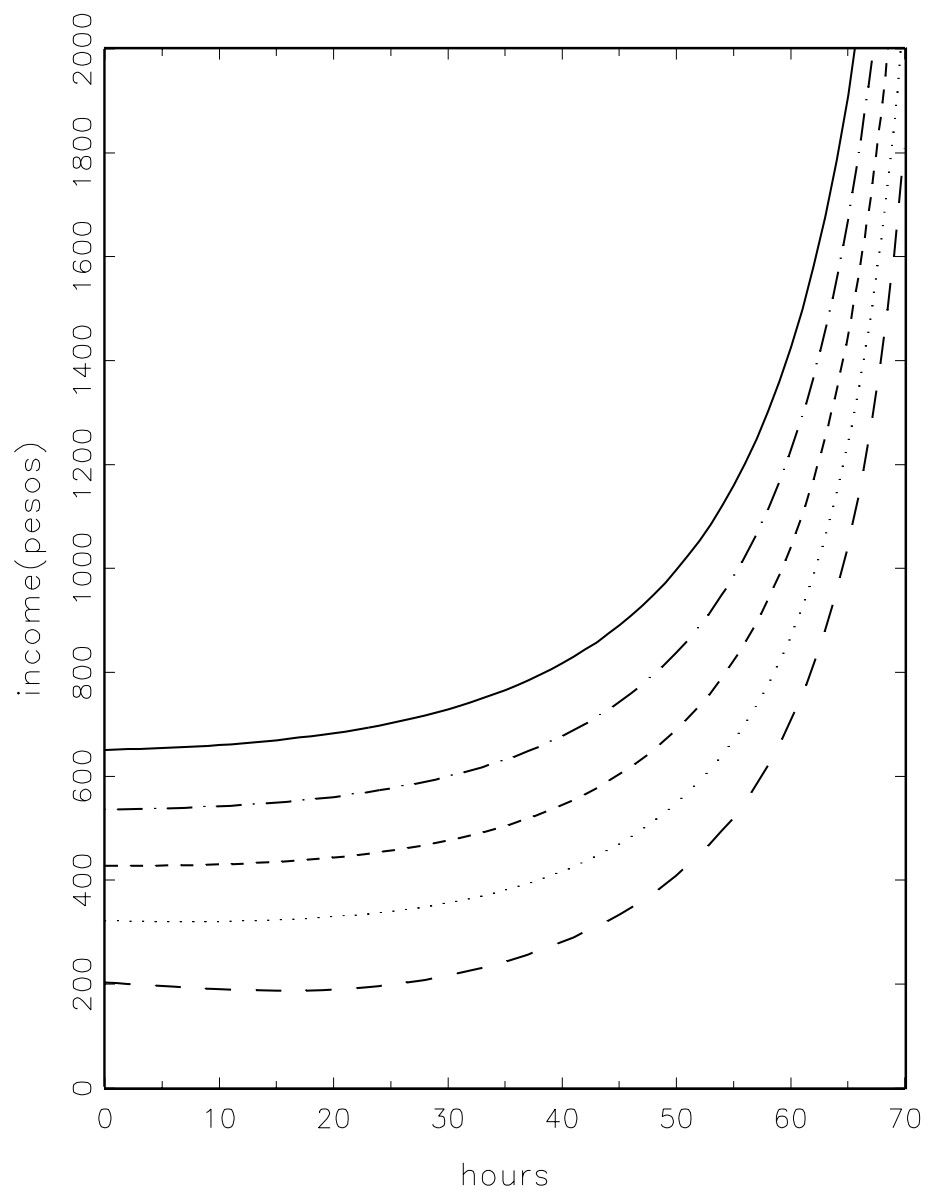


Figure A1. Relationship between after-tax earnings and before-tax earnings (straight line is the fitted one)

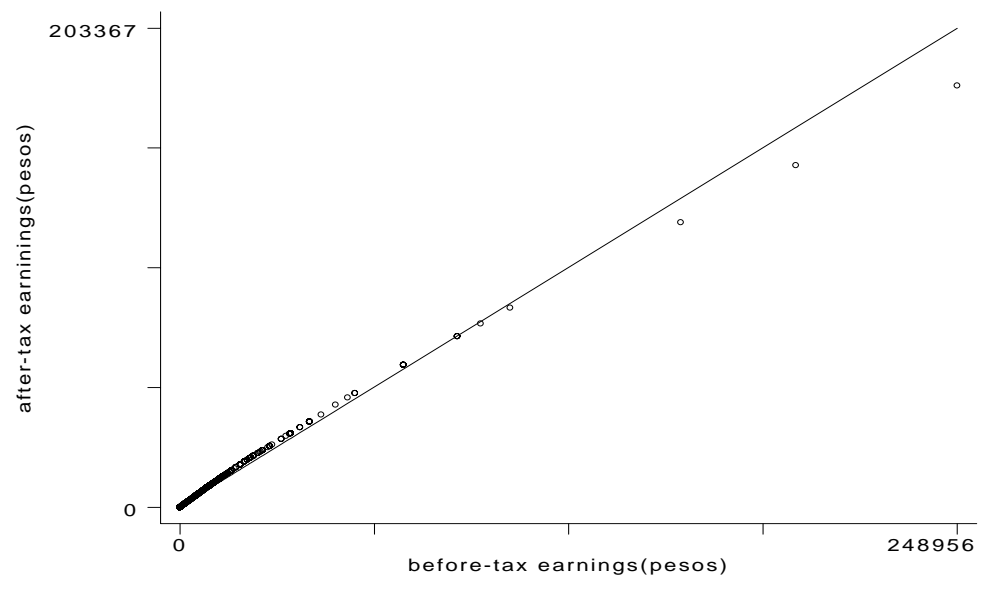




\section{IZA Discussion Papers}

\section{No Author(s)}

121

J. C. van Ours

122

D. Munich

J. Svejnar

K. Terrell

123 J. Hunt

124 R. T. Riphahn

125 F. Büchel

J. R. Frick

\section{J. Fersterer}

R. Winter-Ebmer

M. Karanassou

D. J. Snower

O. Ashenfelter

D. Ashmore

O. Deschênes

B. R. Chiswick

M. E. Hurst
G. Brunello
S. Comi
C. Lucifora

131 B. R. Chiswick

R. A. Hart

D. N. F. Bell

R. A. Hart

O. Hübler

W. Schwerdt

134 A. D. Kugler

G. Saint-Paul

135 A. Barrett

P. J. O'Connell

136 M. Bräuninger

M. Pannenberg

Titel

Area

Date

Do Active Labor Market Policies Help Unemployed $\quad$ 4/6

$3 / 00$

Workers to Find and Keep Regular Jobs?

Returns to Human Capital under the Communist

4

$3 / 00$

Wage Grid and During the Transition to a Market

Economy

Why Do People Still Live in East Germany?

$3 / 00$

Rational Poverty or Poor Rationality? The Take-up 3

$3 / 00$

of Social Assistance Benefits

The Income Portfolio of Immigrants in Germany -

$1 / 3$

Effects of Ethnic Origin and Assimilation. Or:

Who Gains from Income Re-Distribution?

Smoking, Discount Rates, and Returns to

5

$3 / 00$

Education

Characteristics of Unemployment Dynamics: The

Chain Reaction Approach

Do Unemployment Insurance Recipients Actively

Seek Work? Evidence From Randomized Trials in

Four U.S. States

The Employment, Unemployment and

Unemployment Compensation Benefits of Immigrants

The Returns to Education in Italy: A New Look at 5 the Evidence

$3 / 00$

Are Immigrants Favorably Self-Selected? An $\quad 1$

$3 / 00$

Economic Analysis

Hours and Wages in the Depression: British 7 Engineering, 1926-1938

Paid and Unpaid Overtime Working in Germany and 1 the UK

Hiring and Firing Costs, Adverse Selection and

Is There a Wage Premium for Returning Irish

1

$3 / 00$

Migrants?

Unemployment and Productivity Growth: An

3

$3 / 00$

Empirical Analysis within the Augmented Solow Model 
139 R. A. Hart

Y. Ma

140 G. Brunello

S. Comi

141 R. Hujer M. Wellner

142 J. J. Dolado

F. Felgueroso

J. F. Jimeno

143 P. J. Luke

M. E. Schaffer

144 G. Saint-Paul

145 M.-S. Yun

146 T. K. Bauer

J. P. Haisken-DeNew

147 M. Belot

J. C. van Ours

148 L. Goerke

149 R. Lalive

J. C. van Ours

J. Zweimüller

150 J. DiNardo

K. F. Hallock

J.-St. Pischke

$151 \quad$ M. Ward

152 J. J. Dolado

F. Felgueroso

J. F. Jimeno

153 A. S. Kalwij

M. Gregory

154 M. Gerfin

M. Lechner
Wages, Hours and Human Capital over the

Life Cycle

Education and Earnings Growth: Evidence from $11 \quad$ 2/5

European Countries

The Effects of Public Sector Sponsored Training on Individual Employment Performance in East Germany

Explaining Youth Labor Market Problems in Spain: 3 Crowding-Out, Institutions, or Technology Shifts?

Wage Determination in Russia: An Econometric 4 Investigation

Flexibility vs. Rigidity: Does Spain have the worst of 1 both Worlds?

Decomposition Analysis for a Binary Choice Model 7

Employer Learning and the Returns to Schooling 5

Does the Recent Success of Some OECD

Countries in Lowering their Unemployment Rates

Lie in the Clever Design of their Labour Market

Reforms?

Employment Effects of Labour Taxation in an Efficiency Wage Model with Alternative Budget Constraints and Time Horizons

The Impact of Active Labor Market Programs and Benefit Entitlement Rules on the Duration of Unemployment

Unions and the Labor Market for Managers

Gender, Salary and Promotion in the Academic Profession

The Role of the Minimum Wage in the Welfare 3 State: An Appraisal 
A Comparison of the Human Capital and Signaling Models: The Case of the Self-Employed and the Increase in the Schooling Premium in the 1980's

162 C. Dustmann M. E. RochinaBarrachina

Public Employment and Redistributive Politics: 4 
174 E. Fehr J.-R. Tyran

175 M. Lofstrom

176

O. Hübler

W. Meyer

177 B. R. Chiswick

G. Repetto

178 R. Euwals

M. Ward

179 E. Wasmer

P. Weil

180 T. K. Bauer

I. N. Gang

181

E. Wasmer

Y. Zenou

182 M. Fertig

C. M. Schmidt

183 M. Fertig

C. M. Schmidt

184 M. Corak

B. Gustafsson

T. Österberg

185 H. Bonin

K. F. Zimmermann

186

C. Dustmann

187

T. K. Bauer

M. Lofstrom

K. F. Zimmermann
Does Money Illusion Matter? An Experimental Approach

Self-Employment and Earnings among High-

Skilled Immigrants in the United States

Industrial Relations and the Wage Differentials

between Skilled and Unskilled Blue-Collar

Workers within Establishments: An Empirical

Analysis with Data of Manufacturing Firms

Immigrant Adjustment in Israel: Literacy and

Fluency in Hebrew and Earnings

The Renumeration of British Academics

The Macroeconomics of Labor and Credit Market Imperfections

Sibling Rivalry in Educational Attainment:

The German Case

Space, Search and Efficiency

Discretionary Measures of Active Labor Market Policy: The German Employment Promotion Reform in Perspective

Aggregate-Level Migration Studies as a Tool for 1 Forecasting Future Migration Streams

Intergenerational Influences on the Receipt of Unemployment Insurance in Canada and Sweden

The Post-Unification German Labor Market

Temporary Migration and Economic Assimilation

Immigration Policy, Assimilation of Immigrants and Natives' Sentiments towards Immigrants: Evidence from 12 OECD-Countries

The Myth of Worksharing

A. S. Kalwij

A. Zaidi

189

W. Arulampalam
5

2

$8 / 00$ 3

4

$8 / 00$

$8 / 00$

5

$8 / 00$

$7 / 00$

$7 / 00$

$7 / 00$

$7 / 00$

$7 / 00$

$8 / 00$

$8 / 00$

$8 / 00$

$8 / 00$

$8 / 00$

$8 / 00$

3

$8 / 00$
Is Unemployment Really Scarring? Effects of

Unemployment Experiences on Wages 
190 C. Dustmann

I. Preston

191 G. C. Giannelli

C. Monfardini

192

G. Brunello

193

A. Kunze

194

A. Newell

F. Pastore

195 F. Büchel

A. Mertens

196 J. S. Earle

K. Z. Sabirianova

197

G. A. Pfann

198 M. Kreyenfeld

C. K. Spiess

G. G. Wagner

199 H. Entorf

200 T. Bauer

G. S. Epstein

I. N. Gang

201 T. J. Dohmen

G. A. Pfann

202 P. Francois

J. C. van Ours

203 J. M. Abowd

F. Kramarz

D. N. Margolis

T. Philippon

204

G. S. Epstein

205

A. L. Booth

M. Francesconi

J. Frank

206 C. M. Schmidt

R. Baltussen

R. Sauerborn
Racial and Economic Factors in Attitudes to

1

$8 / 00$

Immigration

Joint Decisions on Household Membership and

Human Capital Accumulation of Youths: The role of

5

$8 / 00$

expected earnings and local markets

Absolute Risk Aversion and the Returns to

5

$8 / 00$

Education

The Determination of Wages and the Gender

Wage Gap: A Survey

5

$8 / 00$

Regional Unemployment and Industrial

4

$8 / 00$

Restructuring in Poland

Overeducation, Undereducation, and the Theory

of Career Mobility

5

$9 / 00$

Equilibrium Wage Arrears: A Theoretical and 4

Empirical Analysis of Institutional Lock-In

$9 / 00$

Options to Quit

$9 / 00$

A Forgotten Issue: Distributional Effects of Day

3

Care Subsidies in Germany

$9 / 00$

Rational Migration Policy Should Tolerate Non-

$9 / 00$

Zero Illegal Migration Flows: Lessons from

Modelling the Market for Illegal Migration

What are Migration Networks?

$9 / 00$

Worker Separations in a Nonstationary Corporate 1 Environment

$9 / 00$

Gender Wage Differentials in a Competitive Labor 5

$9 / 00$

Market: The Household Interaction Effect

The Tail of Two Countries: Minimum Wages and 5 Employment in France and the United States

$9 / 00$

Labor Market Interactions Between Legal and

1

$10 / 00$ Illegal Immigrants

Temporary Jobs: Stepping Stones or Dead Ends? $\quad 1$

$10 / 00$

The Evaluation of Community-Based Interventions: Group-Randomization, Limits and

6

$10 / 00$ Alternatives 
